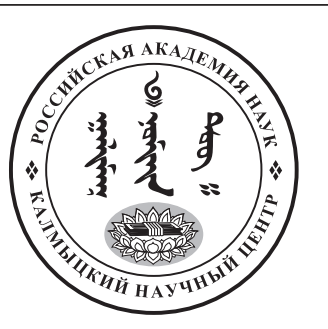

Published in the Russian Federation

Oriental Studies (Previous Name: Bulletin of the Kalmyk Institute

for Humanities of the Russian Academy of Sciences)

Has been issued as a journal since 2008

ISSN: 2619-0990; E-ISSN: 2619-1008

Vol. 14, Is. 5, pp. 937-955, 2021

Journal homepage: https://kigiran.elpub.ru

УДК / UDC 94(47).084.8

DOI: $10.22162 / 2619-0990-2021-57-5-937-955$

\title{
Возвращенная из небытия: борьба за историческую память о 110-й Калмыцкой кавалерийской дивизии. Часть 1
}

\author{
Уташ Борисович Очиров \\ ${ }^{1}$ Калмыцкий научный центр РАН (д. 8, ул. им. И. К. Илишкина, 358000 Элиста, Российская \\ Федерация) \\ доктор исторических наук, доцент, главный научный сотрудник \\ iD 0000-0001-9957-5215. E-mail: utash-ochirov@yandex.ru
}

(C) КалмНЦ РАН, 2021

(С) Очиров У. Б., 2021

\begin{abstract}
Аннотация. Введение. Статья посвящена анализу историографии истории 110-й Калмыцкой кавалерийской дивизии, которая в годы Великой Отечественной войны являлась единственным сражавшимся на фронте национальным соединением, в большинстве своем укомплектованным калмыками. Дивизия достойно показала себя в боях с врагом, но вокруг нее сложились порочащие ее мифы, не соответствующие действительности, а бо́льшая часть ее документов, сданных в архив, исчезла. В результате этого работа по объективному изучению истории соединения растянулась на несколько десятилетий. Материалы и методы. При написании статьи базовым стал историко-генетический метод. Также использовались историко-системный и историко-сравнительный методы. Материалами для статьи послужили книги и статьи, делопроизводственная документация и переписка из различных архивных фондов, личная переписка и воспоминания ветеранов 110-й кавдивизии и исследователей ее истории. Результатьл. В статье последовательно рассматривается историография истории калмыцкого соединения, разделенная на 5 этапов, которые условно можно назвать так: 1) период умалчивания и лжи (19431957 гг.); 2) период «стихийных» поисков (1957-1967 гг.); 3) период активизации научной работы (1967-1977 гг.); 4) период спада (1977-2011 гг.); 5) период нового подъема (с 2011 г. и по настоящее время). Лживые мифы, обвинявшие 110-ю кавдивизию в «неустойчивости», «уходе в банду», а то и вовсе к немцам, придали ее истории политическое звучание. Изучение истории дивизии серьезно осложнила пропажа большей части документов соединения, сданных по описи вместе со знаменами после его расформирования. Это все крайне затруднило процесс по сохранению исторической памяти о единственном калмыцком национальном соединении, сражавшемся на фронте, и его исследователям пришлось приложить титанические усилия для решения этой проблемы. В первой части статьи описаны первый, второй и третий этапы. $B b l-$ водbl. Историография истории 110-й Калмыцкой кавдивизии прошла сложный и извилистый путь, в ходе которого ей пришлось пережить и период забвения, и период активизации.
\end{abstract}


Ключевые слова: Великая Отечественная война 1941-1945 гг., Красная армия, кавалерия; Калмыцкая АССР, национальное соединение, калмыки, историография, исторические мифы, историческая память

Благодарность. Исследование проведено в рамках государственной субсидии - проект «Комплексное исследование процессов общественно-политического и культурного развития народов Юга России» (номер госрегистрации: АААА-А19-119011490038-5).

Для цитирования: Очиров У. Б. Возвращенная из небытия: борьба за историческую память о 110-й Калмыцкой кавалерийской дивизии. Часть $1 / /$ Oriental Studies. 2021. Т. 14 (5). С. $937-$ 955. DOI: 10.22162/2619-0990-2021-57-5-937-955

\title{
The Revived from Oblivion: Struggling for Historical Memory of the $110^{\text {th }}$ Kalmyk Cavalry Division. Part 1
}

\author{
Utash B. Ochirov ${ }^{1}$
}

${ }^{1}$ Kalmyk Scientific Center of the RAS (8, Ilishkin St., 358000 Elista, Russian Federation)

Dr. Sc. (History), Chief Research Associate

0000-0001-9957-5215. E-mail: utash-ochirov@yandex.ru

(C) KalmSC RAS, 2021

(C) Ochirov U. B., 2021

\begin{abstract}
Introduction. The article analyzes historiography and history of the $110^{\text {th }}$ Kalmyk Cavalry Division, the only ethnic Kalmyk (largely) military unit that was engaged in active combat operations during the Great Patriotic War. However, despite its huge contribution to the heroic struggle against invading troops the unit - worthy of decent memory and respect — got surrounded with defamatory myths that bear no relation to actual events. Since most of the Division's documents submitted to archives had disappeared, it took several decades to objectively examine its history. Materials and methods. The historical genetic method being a principal one for the present research, the latter also employs historical systemic and comparative methods. The sources analyzed are books and articles, official documents and correspondence from various archival repositories, personal messages and memoirs by veterans of the $110^{\text {th }}$ Kalmyk Cavalry Division and researchers of its history. Results. The article is a consistent review of the unit's historiography that may be divided into five stages to be designated as follows: 1) period of silence and lies (1943-1957), 2) period of 'sporadic' studies (19571967), 3) period of active scientific work (1967-1977), 4) period of indifference (1977-2011), and 5) period of new scholarly interest (2011 to the present). The Kalmyk Cavalry Division has long been an object of defamatory insinuations and calumny when it was accused of 'unreliability', denounced as a 'gang' or even as German collaborators - these had clearly political implications. Meanwhile, the historical research was seriously complicated by the loss of most of its documents although after the disbandment those were duly handed over according to inventory lists along with the banners. This severely obstructed the process of preserving historical memory of the only ethnic Kalmyk unit that fought against the enemy during the Great Patriotic War. Hence, the difficulties that scholars in the field have had to overcome were immense. Part One of the article covers stages one to three. Conclusions. Historiography of the $110^{\text {th }}$ Kalmyk Cavalry Division may be described as a difficult and winding path, with periods of both oblivion and activation experienced.

Keywords: The Great Patriotic War of 1941-1945, Red Army, cavalry, Kalmyk ASSR, ethnic military unit, Kalmyks, historiography, historical myths, historic memory

Acknowledgements. The reported study was funded by government subsidy, project no. AAAA-A19-119011490038-5 'Sociopolitical and Cultural Development of South Russia's Peoples: Comprehensive Studies of Respective Processes'.

For citation: Ochirov U. B. The Revived from Oblivion: Struggling for Historical Memory of the $110^{\text {th }}$ Kalmyk Cavalry Division. Oriental Studies. 2021. Vol. 14 (5): 937-955. (In Russ.). DOI: 10.22162/2619-0990-2021-57-5-937-955
\end{abstract}




\section{Введение}

В составе Красной армии в период Великой Отечественной войны сражалось нескольких сотен дивизий различных родов войск (стрелковых, кавалерийских, танковых, моторизованных, воздушно-десантных и т. д.). Многие из них многократно отличились в боях, были отмечены различными наградами и почетными наименованиями. Некоторые оказались разгромлены или утратили свое боевое знамя, после чего их расформировали. В ходе тяжелейшей в истории Отечества войны с самым опасным и сильным врагом почти всем пришлось пережить немало драматичных и трагических моментов.

Однако даже среди них история 110-й Калмыцкой кавдивизии выделяется уникальностью своей трагедии. Кому-то 14-месячный срок жизни этого соединения покажется маленьким, но на самом деле это больше, чем у большинства кавдивизий того времени. В те дни, до предела насыщенные различными перипетиями, 110-я кавдивизия приняла неравные бои с армадами панцерваффе, испытала горечь тяжелых отступлений, познала радость побед и освобождения сел и городов нашей Родины. В ходе боев калмыцкое соединение доблестно сражалось, никогда не отступало с поля боя без приказа, нанесло врагу заметный ущерб, сохранило свои знамена. Решение о расформировании было принято из-за того, что кавдивизии из соседнего Кубанского казачьего кавкорпу$\mathrm{ca}$, уже получившего звание гвардейского и овеянного флером славы своего харизматичного командира, понесли заметные потери и требовали пополнения. Хотя опытные воины 110-й кавдивизии в большинстве своем не были казаками, и уж вовсе не являлись кубанцами, но они влились в ряды 4-го гв. Кубанского кавкорпуса и продолжили воевать.

Однако не прошло и года, как весь калмыцкий народ, гордостью которого являлась 110-я кавдивизия, был огульно и несправедливо обвинен в предательстве и выслан в отдаленные районы страны. Воинов-калмыков сняли с фронта и отправили в Широклаг, где от непосильных норм труда и плохого питания многие умерли. Среди широклаговцев оказалось 260 бывших воинов 110-й Калмыцкой кавдивизии [Очиров 2019: 30].

Неудивительно, что научные исследования по истории 110-й Калмыцкой кавдивизии начались с большим опозданием. Мало того, бо́льшая часть документов соединения, сданных после расформирования, в архивный фонд дивизии так и не попала. Вокруг истории национального соединения родилось большое количество мифов, которые заметно исказили ее боевой путь. В результате борьба за возвращение исторической памяти о национальном соединении растянулась на несколько десятилетий и даже продолжается поныне. История этой борьбы, на мой взгляд, представляется крайне интересной для историографии истории Калмыкии и заслуживающей специального исследования.

В целом историография истории 110-й Калмыцкой кавалерийской дивизии делится на 5 этапов, которые условно можно назвать так: 1) период умалчивания и лжи (1943-1957 гг.); 2) период «стихийных» поисков (1957-1967 гг.); 3) период активизации научной работы (1967-1977 гг.); 4) период спада (1977-2011 гг.); 5) период нового подъема (с 2011 г. и по настоящее время).

\section{Материалы и методы}

В ходе работы над статьей был использован широкий комплекс общенаучных и специальных исторических методов. Для данного исследования базовым стал историко-генетический метод, при помощи которого был последовательно описан весь процесс изучения истории 110-й Калмыцкой кавалерийской дивизии. Для периодизации процесса и выделения в нем отдельных этапов был использован историко-системный метод. Для сравнения деятельности исследователей на разных этапах применялся историко-сравнительный метод. Как и для любого историографического исследования, базовым материалом стал комплекс книг и статей из научных журналов, связанных с историей 110-й Калмыцкой кавдивизии. Кроме того, в ходе работы использова- 
лись такие источники, как публицистика, личная переписка и воспоминания ветеранов и исследователей-историков, делопроизводственная документация и переписка, хранящиеся в Центральном архиве Министерства обороны РФ (далее - ЦАМО) и Научном архиве Калмыцкого научного центра РАН (далее - НА КалмНЦ РАН).

\section{Период умалчивания и лжи}

После депортации калмыцкого народа даже сам этноним «калмык» оказался под запретом, а название и номер 110-й кавдивизии - преданы забвению. Даже когда в различных трудах описывали опыт боев калмыцкого национального соединения, то его номер и название опускались. Например, Штаб сухопутных войск Вооруженных сил СССР, который после Великой Отечественной войны опубликовал ряд сборников, обобщив в них боевой опыт, в 1949 г. выпустил сборник тактических примеров боевых действий кавалерийского полка.

Одним из таких примеров, выбранных в качестве эталонных, стала оборона 273-го (Сарпинского) кавалерийского полка на р. Дон в июле 1942 г. [Оборона... 1949: 82-87]. Следует заметить, что уставными документами использование кавалерии в обороне не предусматривалось. Понятно, что в годы войны бывали всякие ситуации, и кавалерийские соединения могли вынужденно использоваться в обороне, но оборона на участке 58 км (пусть даже на речном рубеже) была уникальным явлением. Неудивительно, что для примера обороны был выбран кавалерийский полк именно 110-й кавдивизии, хотя в статье ни слова не было о том, что эта часть преимущественно состояла из калмыков, высланных к тому времени в Сибирь. При этом сведения о боях в этом районе были даны с большими ошибками. Например, утверждалось, что с правого фланга 273-й кавполк прикрывала 51-я кавдивизия (которая в это время на самом деле находилась в Забайкалье); даты боев были даны с ошибками; неправильно описывались течение боя и расстановка сил [Оборона... 1949: 82-87].

Еще сильнее реальную историю 110-й кавдивизии искажали мифы, которые сложились еще в годы войны. Следует заметить, что самые первые мифы о калмыцком соединении стали складываться еще в годы войны. Например, командующий 24-й армией Южного фронта генерал-майор В. Н. Марцинкевич 23 июля 1942 г. обвинил командование 110-й кавдивизии в плохой подготовке оборонительного рубежа. На самом деле его армия, отступавшая к берегу Дона, избежала уничтожения только благодаря тому, что калмыцкое соединение, не имея ни зенитной артиллерии, ни авиационного прикрытия, защитило и уберегло от многочисленных ударов люфтваффе все переправы через Дон на своем 58-километровом участке [Заярный, Очиров 2017: 50-59]. Именно армии В. Н. Марцинкевича директивой № 0414/оп Южного фронта было поручено к утру 22 июля занять оборону на южном берегу Дона от устья Маныча до Ново-Золотовской (на самом деле бо́льшую часть этого рубежа удерживали как раз воины 110-й кавдивизии), обеспечив переправу отступающих войск [ЦАМО. Ф. 224. Оп. 760. Д. 6. Л. 114-116]. Однако дивизия «Великая Германия» внезапным ударом отрезала это объединение от Дона, и разрозненным остаткам 24-й армии пришлось прорываться через редкие порядки противника к переправам, продолжавшим работать только благодаря мужеству воинов 110-й кавдивизии.

Вместо благодарности В. Н. Марцинкевич подверг критике командование национального соединения за якобы плохую подготовку обороны на берегу Дона. Однако командующий Южным фронтом Р. Я. Малиновский, который переправился через Дон в Багаевской и лично видел калмыцкое соединение в деле, был другого мнения, и после его переговоров со Ставкой вечером 22 июля 110-ю кавдивизию и 156-ю стрелковую дивизию передали из состава 51-й армии Северо-Кавказского фронта в 37-ю армию Южного фронта [ЦАМО. Ф. 96а. Оп. 2011. Д. 26. Л. 151-157].

В. Н. Марцинкевич из-за потери управления войсками, понесшими значительные потери, так и не смог выполнить полученные приказы о занятии позиций на Дону. В итоге 24 июля управлению 24-й армии поручили отвести в тыл остатки частей, лишившихся вооружения. То, что толпа безоружных солдат смогла дойти до Терека без особых потерь и оторваться от преследующих их колонн панцерваффе, было заслугой войск 37-й армии (в том числе 110-й кавдивизии), задержавших немцев в жесто- 
чайших арьергардных боях. Тем не менее В. Н. Марцинкевич, возглавивший после расформирования 24-й армии 8 августа 9-ю армию, продолжал отрицательно относиться к 110-й кавдивизии, которая 13 августа вышла в полосе его действий и была ему подчинена. По всей видимости, именно по его инициативе командир 110-й кавдивизии калмык В. А. Хомутников (бывший председатель КалмЦИК и Верховного совета Калмыцкой АССР, пользовавшийся среди бойцов соединения высочайшим авторитетом) был заменен на постороннего «варяга». Лишь 28 августа В. Н. Марцинкевича отстранили от должности и отправили в тыл с понижением.

Еще дальше зашел в этом плане штаб 51-й армии, заявивший, что 110-я кавдивизия «ушила в банды». Источник происхождения этого слуха был четко указан в письмах первого секретаря Калмыцкого обкома П. В. Лаврентьева и председателя Совнаркома Калмыцкой АССР Н. Л. Гаряева, с возмущением писавших об этом заместителю наркома обороны Е. А. Щаденко и другим руководящим лицам: «Между тем о 110 К.Д. в сентябре-октябре месяџах распространились различные провокачионные разговоpы, якобы дивизия разбрелась и занимается бандитизмом. Например, штаб 51-й армии официально сообщил Военному совету Северной группы Закфронта о том, что будто бы полковник Хомутников с личнылм составом около 2000 человек ушел в неизвестное направление в банду. Чем руководствуется итаб 51-й армии нам неизвестно» [НА РК. Ф. Р-131. Оп. 3. Д. 86. Л. 132].

Поскольку П. В. Лаврентьев и Н. Л. Гаряев в сентябре-октябре 1942 г. неоднократно встречались с В. А. Хомутниковым и видели саму дивизию, которая после отхода с Дона по приказу Северной группы Закавказского фронта защищала железную дорогу Астрахань - Кизляр, то для них лживость таких утверждений была очевидной. Среди бумаг Н. Гаряева, хранящихся в Национальном архиве Республики Калмыкия (далее - НА РК), есть и черновые варианты этого письма, которое автор неоднократно и кардинально переделывал, вычеркивая или дописывая целые абзацы или даже страницы. В одном из зачеркнутых абзацев после слов «нам неизвестно» было дописано: «Видимо шттаб этой (51-й. - У. О.) армии сообщил об этом Наркомату обороны, так как 9.10.1942 года из Наркомата обороны по телефону просили у командующего 28 армии генерал-лейтенанта Герасименко [сведения] по тому же вопросу» [НА РК. Ф. Р-131. Оп. 3. Д. 86. Л. 139].

Следует заметить, что 110-я Калмыцкая кавдивизия входила в состав 51-й армии с 12 июня 1942 г. и начальную фазу боев на Дону прошла именно в ее составе. Однако фронт обороны шириной почти 700 км, занимаемый 51-й армией, был слишком большим, поэтому, как уже упоминалось выше, 23 июля левофланговые соединения (110-я кавалерийская дивизия и 156-я стрелковая дивизия) этого объединения были переданы в состав 37-й армии. К тому же танки и мотопехота 4-й танковой армии создали плацдармы у Цимлянской и Николаевской и, выйдя передовыми частями к р. Сал, разрезали фронт 51-й армии, фактически отрезав вышеуказанные левофланговые соединения от штаба.

С 23 июля сведения о реальном положении дел 110-й кавдивизии штаб 51-й армии мог получать лишь окольными путями, например от командования Северо-Кавказского фронта. Однако в последующих боях 51-я армия оказалась отрезана и от фронтового командования, была разбита и отошла на восток, войдя в подчинение командования Сталинградского фронта. От 110-й кавдивизии 51-ю армию отделяли сотни километров, но штабисты почему-то сочли возможным тиражирование этого лживого мифа.

Его появление сразу привело к политическим последствиям: заметно ухудшилось отношение военных властей к калмыкам. Вот что писал об этом первый секретарь Калмыцкого обкома ВКП(б) П. В. Лаврентьев в докладе от 18 ноября 1942 г.: «110 Калмыикая кавалерийская дивизия... с боями отходила на юг. В августе-сентябре месяиах этого года главные силь дивизии в количестве 2000 человек под командованием полковника Хомутникова вышли к Кизляру, зачислены в состав 44 армии Закавказского фронта и сейчас находятся на линии Кизляр - Черный Рынок. В то же время ктото усердно стал распространять слухи, что якобы т. Хомутников с 2000 человек ушел в банды. Эта провокачия дошла даже до т. Щаденко. В частях 28 и 51 армии от- 
дельные командиры смотрят на калмыков как на отсталую часть и как на сплошных бандитов. Всякий верховой калмык, встреченный в степи, изображается бандитом. Примером этого является такой факт: представители 28 армии решили выслать из с. Юсть и Эрдниевки Юстинского улуса всех калмыков, а население других наџиональностей оставить на месте и только после нашего вмешательства эта грубая политическая ошибка была исправлена военныл советом 28 армии» [НА РК. Ф. П-1. Оп. 20. Д. 24. Л. 69].

Указанное в письме П. В. Лаврентьева выселение из Юстинского улуса проводилось согласно приказу Сталина о выселении населения из 25-километровой прифронтовой полосы. Перед этим, 15 октября 1942 г., Калмыцкий обком и Совнарком Калмыцкой АССР договорились с управлением 28-й армии, что выселение людей из указанных сел будет завершено без спешки, к 10 ноября после обмолота и вывоза хлеба. Однако 20 октября войска внезапно вывезли оттуда всех калмыков, оставив представителей других национальностей на месте [НА РК. Ф. Р-131. Оп. 3. Д. 86. Л. 120, 129].

В. Б. Убушаев в одной из работ о депортации калмыков, ссылаясь на слова В. М. Молотова, сказанные ему в личной беседе в 1974 г., указал в качестве источников мифа о «разбежавшейся» 110-й Калмыцкой кавдивизии «донесения командования 37-ой и 51-ой армий» [Убушаев 2007: 152]. По утверждению В. Б. Убушаева, именно заявление Г. К. Жукова на заседании ГКО о том, что 110-я кавдивизия «разбежалась», со ссылкой на донесения 37 и 51-й армий, имело ключевое значение при принятии решения о высылке всего калмыцкого народа на спецпоселение [Убушаев 2007: 152-153].

В другой работе В. Б. Убушаев привел фрагмент воспоминаний управляющего делами Совнаркома Калмыцкой АССР С.-Г. М. Манджиева. Накануне депортации, вечером 27 декабря 1943 г., в кабинете первого секретаря Калмыцкого обкома был собран «руководящчий партийно-советский состав республики», на котором комиссар государственной безопасности 2-го ранга И. А. Серов сообщил о высылке калмыцкого народа. Заместитель председателя Совнаркома Калмыцкой АССР Д. Г. Гахаев задал вопрос о причинах депортации калмыцкого народа «в целом». Заместитель наркома НКВД СССР отлично знал, что обвинения, приведенные в Указе Президиума Верховного совета СССР от 27 декабря 1943 г. и переписанные под копирку из другого аналогичного акта, не соответствуют действительности. Поэтому он дал такой ответ: «На этот вопрос, помню, Серов сказал: „Ваша дивизия цееликом разбежалась и ушла к немцам“. Затем, некоторое время помолчав, вдруг сказал, махнув рукой: „И этот ваи Городовиков". Совершенно было непонятно, что он имел под этим в виду» (цит. по: [Убушаев 1991: 18-19]).

Характерно, что еще в начале 1943 г. заместитель наркома НКВД СССР С. Н. Круглов писал, что попытки оккупантов создать коллаборационистский корпус из калмыков успеха не имели. Но в последующем позиция «энкавэдэшников» изменилась. В июле 1944 г. в справке о борьбе с бандитизмом за три года войны начальник отдела по борьбе с бандитизмом НКВД СССР комиссар госбезопасности 2-го ранга А. М. Леонтьев фрагмент о Калмыкии начал так: «Находившаяся на фронте в районе Ростова-на-Дону 110 калмыцкая национальная кавалерийская дивизия проявила неустойчивость. В частях дивизии началось массовое дезертирство. Дезертиры группами, в некоторых случаях со своими командирами, возврашались домой и среди населения распускали всевозможные пораженческие слухи. С приближением фронта к Калмыкии... из дезертиров 110-й дивизии они создали крупные банды, которые свочми действиями сорвали эвакуацию скота из Калмыкии... немецкое командование сформировало из бандитско-дезертирского элемента калмыцкий кавалерийский легион, состоящчий из 14 эскадронов» [НКВД-МВД... 2008: 525]. Из этого следует, что национальное соединение не просто разбежалось, а еще и послужило основой для коллаборационистского формирования.

На самом деле никакого массового дезертирства в боях на Дону не было. Во время отступления на Кавказ некоторые части получали противоречивые приказы, в результате чего отделились от основного ядра 110 -й кавдивизии и прибыли в другие районы сосредоточения, где влились в состав 17-го казачьего кавкорпуса и 28-й армии. 
Некоторые подразделения при прорыве из окружения или в ходе арьергардных боев также отделились от основного ядра, но вышли к позициям своих войск самостоятельно. Некоторым из них удалось вернуться в состав 110-й кавдивизии.

Конечно, отдельные группы или одиночные «безлошадные» бойцы отстали от основных сил и, не зная пункта назначения, повернули домой. Однако многие из них, откормившись, вновь вернулись в Красную армию. Среди тех, кто реально совершил дезертирство, не было ни одного офицера. Только один офицер-калмык (лейтенант Санчир Коноков) после боев на Дону, попав в плен, стал сотрудничать с немцами. Он оказался единственным калмыком-офицером, ставшим коллаборационистом. Оккупировав часть территории Калмыкии, немцы действительно создавали коллаборационистские эскадроны, но ни один из них не формировался из какой-либо группы дезертиров 110-й кавдивизии.

Таким образом, мифы о то ли «разбежавшейся», то ли уже «ушедшей к немцам» 110-й кавдивизии - это уже не просто частный военный эпизод, а важнейшее событие, имевшее далеко идущие последствия для всего калмыцкого народа и для советской национальной политики в целом. Активное тиражирование мифов о «разбежавшейся дивизии» привело к тому, что многие жители страны, включая профессиональных историков, поверили в них. Среди них оказались даже некоторые наши земляки.

\section{Период «стихийных» поисков}

После восстановления автономии Калмыкии ситуация изменилась. Слово «калмык» перестало иметь негативную коннотацию, сами калмыки стали возвращаться на родину. Был восстановлен Калмыцкий научно-исследовательский институт истории, языка и литературы (далее - КНИИЯЛИ, ныне - Калмыцкий научный центр РАН), в котором начал работу сектор истории. К сожалению, возможности для набора кадров у института в тот момент оказались ограничены. В период депортации существовал негласный запрет на прием спецпереселенцев на педагогические специальности (в том числе исторические), и обойти его удалось немногим. Среди них был М. Л. Кичиков, сыгравший в историографии истории 110-й кавдивизии важную роль.
Мерген Лиджинович Кичиков (19221999) родился в станице Иловайская (Зюнгарская) Области Войска Донского. В 1941 г. он был призван в ряды Красной армии, окончил артиллерийское училище. В 1943-1945 гг. командовал взводом, затем батареей 256-й стрелковой дивизии Волховского, Ленинградского и 2-го Прибалтийского фронтов. М. Л. Кичиков принимал участие в прорыве блокады Ленинграда, Мгинской операции, «Январском громе», освобождении Нарвы, боях на территории Латвии, под Лиепаей и Тукумсом, блокаде курляндской группировки. В период сражений Мерген Лиджинович был трижды ранен, за отличия в боях награжден орденами Красной Звезды и Отечественной войны 2-й степени.

В 1946 г. он демобилизовался и убыл на спецпоселение в Казахстан. В 1952 г. Мерген Лиджинович окончил исторический факультет Казахского пединститута им. Абая в Алма-Ате. Работал учителем, затем директором школы в Усть-Каменогорске. После возвращения из депортации работал инспектором Приозерного районного отдела народного образования.

В 1961 г. М. Л. Кичиков был принят старшим научным сотрудником в сектор истории КНИИЯЛИ и поступил в аспирантуру Института востоковедения АН СССР. В 1963 г. он защитил кандидатскую диссертацию по истории вхождения калмыков в состав России и образования Калмыцкого ханства в XVII в., а в 1965 г. - возглавил сектор истории. В дальнейшем М. Л. Кичиков в ходе исследований по истории участия Калмыкии в Великой Отечественной войне собрал и проанализировал огромный массив информации. На его основе он написал диссертацию, которую защитил в 1972 г., став первым калмыком - доктором исторических наук [Очиров, Тепкеев 2017: 112-117].

Сектору истории КНИИЯЛИ пришлось решать большой спектр задач, в том числе и по написанию фундаментального обобщающего труда «Очерки истории Калмыцкой АССР». После подготовки к изданию в 1964 г. сборника документов об участии калмыков в войне 1812-1814 гг. М. Л. Кичиков с Б. С. Санджиевым (окончившим Саратовский пединститут в 1932 г.) и Ю. О. Оглаевым (окончившим Астрахан- 
ский пединститут в 1960 г.) приступил к работе по составлению сборника документов и материалов по истории участия Калмыкии в Великой Отечественной войне. До них эту проблематику никто не рассматривал, и они стали зачинателями этого направления в исторической науке республики.

Одной из наиболее сложных проблем, с которой пришлось столкнуться исследователям, оказалась нехватка архивных документов. После расформирования 110-й кавдивизии в феврале 1943 г. весь ее архив вместе со знаменами вывезли в Москву и сдали по описи в штаб кавалерии Красной армии. Однако, когда в 1960-х гг. исследователи начали поиск этих документов в Центральном архиве Министерства обороны (далее - ЦАМО), то обнаружили, что в фонде 110-й кавдивизии имеется примерно $10 \%$ документов, сданных по описи. При этом в оставшихся делах полностью отсутствовали оперативные документы и карты, по которым можно было бы определить боевой путь соединения и степень его участия в тех или иных боях. Летопись 110-й кавдивизии не велась изначально, и исторический формуляр на нее не составлялся.

Кроме того, на составителей сборника документов давила предъюбилейная спешка. В результате этого в сборник вошло всего 28 документов по истории 110-й кавдивизии, выделенные в специальный блок [Калмыкия... 1966: 156-195]. Из них 17 документов (почти две трети) являлись наградными листами, которые хорошо показывали храбрость и доблесть воинов национального соединения, но мало что говорили о его боевом пути и реальном участии в сражениях. Среди других документов встречались весьма информативные, например, письма и доклады командования 110-й кавдивизии, датированные 6 сентября, не ранее 10 октября, 26 декабря 1942 г., но этого было явно недостаточно. Поэтому составители сборника решили восполнить пробел за счет наиболее информативных воспоминаний ветеранов. В ходе поисковой работы они неоднократно давали интервью в газетах и на радио, рассказывали о своей деятельности, просили участников войны предоставить свои документы и воспоминания. К сожалению, ветеранов национального соединения тогда откликнулось немного.
Многие ветераны погибли еще в годы войны, в том числе наиболее информированные из них: два командира 110-й кавдивизии В. П. Панин и В. А. Хомутников (два других командира А. И. Лисицын и В. К. Терентьев командовали соединением 9 и 11 дней соответственно и не успели полностью вникнуть в его дела) и два комиссара С. Ф. Заярный и В. А. Максютов (из трех). Значительная часть офицеров из числа тех, кто уцелел в боях, проживала в разных городах по всей стране и не поддерживала связь между собой. Некоторые ветераны к тому времени уже умерли.

Среди тех, кто откликнулся, был бывший заместитель начальника, затем начальник политотдела 110-й кавдивизии Н. Л. Иванов. В 1958-1959 гг. он являлся председателем Президиума Верховного Совета Калмыцкой АССР, затем его сняли с должности. Только в 1969 г. выяснилось, что Намса Иванов был аферистом и подделал ряд своих документов, в том числе диплом о высшем образовании, о высшей вневойсковой подготовке (и соответственно - звания офицера запаса), справки о ранениях, наградные листы на два ордена Красного Знамени. Судьи, шокированные таким цинизмом, приговорили ветерана-инвалида по «легким» в общем-то статьям (лжесвидетельство, использование поддельных документов, злоупотребление властью, угроза должностному лицу) к 8 годам колонии строгого режима. Лишь спустя год ему удалось добиться от Л. И. Брежнева смягчения наказания [Очиров 2018: 122-127].

В середине 1960-х гг. об этом еще известно не было, поэтому составители сборника документов отнеслись с доверием к словам бывшего номенклатурного работника и проректора пединститута. И именно его воспоминания были выбраны для того, чтобы восполнить недостаток архивных источников по истории 110-й кавдивизии [Калмыкия... 1966: 196-206]. В своих воспоминаниях Н. Л. Иванов «выпячивал» себя, в том числе путем подтасовок и «принижения» роли соратников. Например, он писал, что был начальником политотдела национального соединения с весны 1942 г. (на самом деле им был А. И. Заднепрук, тяжело раненный 26 июля в боях на Дону, только после этого его сменил Н. Л. Иванов). О первом комиссаре 110-й кавдивизии 
С. Ф. Заярном аферист написал, что тот пропал без вести «в районе Ставрополя у села Донское» [Материалы... 1970: 304], хотя на самом деле комиссар пал смертью храбрых еще в боях на Дону.

В воспоминаниях Н. Л. Иванова не нашлось места ни преемникам Заярного (непосредственным начальникам Намсы Лиджиновича) - комиссарам В. А. Максютову и В. Т. Швецу, ни командирам и комиссарам полков, ни многим офицерам из управления 110-й кавдивизии, в том числе тем, кто сыграл ключевую роль при формировании национального соединения.

Ситуацию усугубила еще одна ошибка, допущенная, по словам М. Л. Кичикова, изза неточности в учетных документах Главного управления кадров Министерства обороны СССР, в которых утверждалось, что В. А. Хомутников командовал 110-й кавдивизией с мая 1942 г. [НА КалмНЦ РАН. Ф. 4. Оп. 4. Д. 246. Л. 9-10]. По-видимому, из-за этого ошибку повторил и министр обороны А. А. Гречко в воспоминаниях о Битве за Кавказ: в Приложении № 2 командиром 110-й кавдивизии (с 20 мая 1942 г.) значился только В. А. Хомутников [Гречко 1967: 483].

В результате составители сборника, опубликованного в 1966 г., в абзацах введения, посвященных 110-й кавдивизии, не упомянули фамилии первых командира и комиссара, которые формировали соединение и обучали его в течение нескольких месяцев, а затем повели в бой против «Великой Германии». Документы за подписями В. П. Панина и С. Ф. Заярного в сборнике отсутствовали, за исключением «Письма-клятвы» воинов 110-й кавдивизии, подписанного почти четырьмя десятками человек. Не были упомянуты имена командиров и комиссаров соединения и частей, о которых составители сборника не знали.

В комментариях к одному из документов утверждалось, что Н. Л. Иванов являлся начальником политотдела 110-й кавдивизии с весны 1942 г. [Калмыкия... 1966: 442]. Мало того, газета «Советская Калмыкия» в номере от 7 мая 1965 г. написала, что «в летний период 1942 года комиссаром 110 ОККД являлся батальонный комиссар Иванов» (цит. по: [Материалы... 1970: 305]).
Конечно, эта ложь вызвала возмущение у многих ветеранов 110-й кавдивизии, особенно служивших в ней в период формирования. И в этот момент особую роль сыграл бывший командир пулеметного эскадрона 292-го кавполка Н. В. Бадьминов. Вообще его вклад в историю 110-й кавдивизии весьма значителен.

Николай Васильевич Бадьминов (1914??) родился в станице Эркетинская Области Войска Донского. В 1932-1936 гг. служил в Красной армии, окончил военно-ветеринарное училище. В 1941 г. его повторно призвали в армию. Он работал преподавателем конного дела во 2-м Орджоникидзевском училище, а с декабря 1941 г. Н. В. Бадьминов в числе первых офицеров прибыл в 110 -ю кавдивизию. Он был назначен командиром пулеметного взвода 292-го кавполка, затем стал заместителем командира и командиром пулеметного эскадрона того же полка, вместе с которым принял участие в первых и самых тяжелых боях национального соединения на Дону.

26 июля 1942 г. Н. В. Бадьминов в составе 292-го кавполка оборонял Карповку, а когда пришел приказ об отходе, вместе со своими пулеметчиками прикрыл отход полка. В том бою его эскадрон был уничтожен полностью, а тяжело раненный Н. В. Бадьминов попал в плен. Несмотря на незажившие раны, он бежал и вышел к своим. После проверки в фильтрационном лагере служил командиром взвода во 2-м запасном кавполку, добился направления на фронт, в 5-й гв. Донской казачий кавкорпус. Там Н. В. Бадьминов был назначен командиром сабельного взвода 43-го гв. кавполка, с которым дошел до Румынии, был ранен и вновь отправлен в военное училище для преподавания конной езды.

После войны Н. В. Бадьминов неоднократно выезжал на места боев на Дону, позже и вовсе поселился в хуторе Карповка, в котором потерял свой эскадрон. Он беседовал с местными жителями - очевидцами и их потомками, разыскивал захоронения соратников из 110-й кавдивизии, в том числе полкового комиссара С. Ф. Заярного. Он постоянно искал своих сослуживцев, устанавливал с ними связь, вел активную переписку.

В 1966 г. Николай Васильевич разыскал детей Заярного и рассказал об обстоя- 
тельствах и месте гибели и захоронения их отца. Для них С. Ф. Заярный почти четверть века считался пропавшим без вести, что в те годы было весьма многозначно и могло подразумевать возможность попадания военнослужащего в плен. Дети Сергея Федоровича искали место его гибели в Крыму, поскольку в архивной справке говорилось о том, что он пропал без вести, сражаясь в составе 51-й армии, в июне (выделено мною. - У. О.) 1942 г. На рассказы вдовы о том, что она жила в Калмыкии, приезжала к мужу на Дон, что ей привозил посылку от мужа полковник-калмык В. А. Хомутников, тогда дети внимания не обратили. Поэтому рассказ Н. В. Бадьминова о героической гибели С. Ф. Заярного с указанием правильной даты и точного места гибели снял, как говорится, «камень с души» потомков Сергея Федоровича.

Сын комиссара - офицер Советской армии Альберт Заярный подружился с Н. В. Бадьминовым и М. Л. Кичиковым, активно включился в поиск ветеранов 110й кавдивизии. Некоторые из них сами стали выходить на связь с сыном комиссара соединения. В 1967 г. А. С. Заярный с помощью бывшего офицера штаба дивизии Г. И. Бурмистрова, в то время работавшего в Ростовском облвоенкомате, организовал эксгумацию и перезахоронение тела отца.

Н. В. Бадьминов часто выступал в роли своеобразного «гида» для профессиональных историков. Неслучайно М. Л. Кичиков, описывая свою первую поездку на места боев на Дону вместе с Н. В. Бадьминовым и инструктором обкома ВЛКСМ И. С. Манджиковым, подчеркнул: «Н. В. Бадьминов помог нам увидеть и усльпшать на Дону многое. Mы увидели нечто грандиозное» [Материалы... 1970: 301]. А в одном из писем М. Л. Кичиков, выражая досаду на нехватку информации по 273-му и 311-му кавполкам, писал: «Жаль, что в этих полках не нашлось своих Бадминовых» [НА КалмНЦ РАН. Ф. 4. Оп. 4. Д. 62] $]^{1}$.

После выхода сборника документов с воспоминаниями Н. Л. Иванова Н. В. Бадьминов купил несколько экземпляров книги, а также добавил вырезки из газеты «Хальмг үнн», в которой Намса Лиджинович был

${ }^{1}$ В этом деле раздельная пагинация, поэтому номера листов не указываются. назван комиссаром калмыцкого соединения, и разослал ветеранам. Некоторые из адресатов откликнулись и направили письма в КНИИЯЛИ, на имя составителей сборника. В их числе были бывшие офицеры из управления и штаба 110-й кавдивизии (начальник штаба И. А. Теврюков из Иванова, начальник оперативного отдела Г. И. Бурмистров из Ростова, начальник политотдела А. И. Заднепрук из Киева, прокурор Д. С. Лебедкин из Луганска), бывшие командир и комиссар 292-го кавполка С. И. Ориночко и П. А. Кругляков из Краснодара и др. [НА КалмНЦ РАН. Ф. 4. Оп. 4. Д. 59, 61, 88, 210].

В своих письмах они, помимо всего прочего, разоблачили ложь Н. Л. Иванова и защитили честное имя В. П. Панина и С. Ф. Заярного. Кроме того, ими был поставлен вопрос о необходимости более углубленного изучения истории 110-й кавдивизии, в том числе за счет активного привлечения воспоминаний участников тех событий.

Стоит также упомянуть о том, что в этот период начали публиковаться воспоминания участников войны из Калмыкии. В их числе были мемуары бывшего командира 311-го кавполка М. С. Шарапова [Шарапов 1966]. К сожалению, Маркел Санжинович убыл из 110-й кавдивизии еще до начала боев, а период формирования в его воспоминаниях был рассмотрен им фрагментарно.

Период активизации научной работы

Для историографии истории 110-й кавдивизии переломным стал 1967 г. КНИИЯЛИ, получив большую базу адресов ветеранов, стал организовывать различные мероприятия, встречи и другие общественно-политические акции с их участием.

15-25 июля 1967 г. сотрудники института и три ветерана (бывший заместитель командира дивизии М. Т. Бимбаев, Н. В. Бадьминов, бывший шофер штаба C. М. Сармуткин) приняли участие в комсомольско-молодежном мотопоходе на Дон, организованном Калмыцким обкомом ВЛКСМ. Командиром мотопохода был секретарь обкома ВЛКСМ К. П. Катушов (сын офицера 110-й кавдивизии), комиссаром М. Л. Кичиков.

Участники мотопохода за 11 дней объехали пол-Калмыкии, побывали на местах 
боев 110-й кавдивизии на Дону, выслушали рассказы местных жителей о тяжелейшем сражении и героизме воинов калмыцкого соединения, произвели раскопки. После поездки М. Л. Кичиков писал: «Сейчас можно с уверенностью сказать, что здесь совершили подвиг не отдельные солдаты и офииеры, а ичелое соединение» [В боях за Дон 1969: 8]. В другой работе он подчеркнул: «Предварительная поездка... оставила неизгладимое впечатление: здесь все говорило о героизме, трагизме и величии происходившего в июле 1942 года. Величие состояло в упорстве, высоком сознании долга и силе духа людей, которые выполняли заведомо непосильную задачу - прикрывать отход наших войск, стоять насмерть, чтобь задержать на Дону хоть на несколько часов и дней лавину танковых, мотомеханизированных сил врага» [НА КалмНЦ РАН. Ф. 4. Оп. 4. Д. 246. Л. 6].

Осенью 1967 г. КНИИЯЛИ организовал собрание ветеранов 110-й кавдивизии, в том числе и иногородних. Перед этим институт организовал поездку на Дон, по местам первых боев калмыцкого соединения (с 24 по 30 сентября), в которой приняли участие: бывшие офицеры управления 110-й кавдивизии (М. Т. Бимбаев, А. И. Заднепрук, Д. С. Лебедкин, И. А. Теврюков, Г. И. Бурмистров), ветераны 292-го кавполка (С. И. Ориночко, П. А. Кругляков, Н. В. Бадьминов, бывшие особист П. А. Шувадуров, политрук эскадрона О. С. Чурюмов, пом. командира взвода И. Т. Базюк), ветераны 311-го кавполка (бывшие командир полка М. С. Шарапов, комсорг М. И. Гучинов, командир взвода И. А. Скоробогатов, старшина В. Т. Точка), а также сын комиссара дивизии А. С. Заярный. В станице Багаевской к ним присоединился бывший командир взвода 292-го кавполка И. И. Лобоченко.

Ветераны почтили память сослуживцев, записали воспоминания местных жителей. Эта поездка имела большое значение для историков и ветеранов. П. А. Кругляков об этой поездке вспоминал так: «Со времени боев на Дону прошло немало лет и вполне естественно, что многое забылось. Посещение мест боев почти наполовину восстановило забытое. В этом колоссальное значение поездки» [Расширенное заседание... 1970: 316]. С другой стороны, поездка на- кануне 50-летия революции носила официальный характер, и работа делегации была ограничена во времени. П. А. Шувадуров в выступлении по итогам мероприятия подчеркнул: «Во время поездки мы прямо-таки бегом осматривали позиции 292-го полка. Я считаю, что нужна систематическая работа, а не эпизодическая» [Расширенное заседание... 1970: 317].

После этого в КНИИЯЛИ состоялось совещание, в котором приняли участие ветераны 110-й кавдивизии. Участники совещания подвергли жесткой критике Н. Л. Иванова за его ложь и подчеркнули необходимость изучения истории калмыцкого национального соединения. 2 октября 1967 г. Ученый совет КНИИЯЛИ постановил включить в план работы сектора истории тему научно-исследовательской работы по истории 110-й кавдивизии. Сектору поручили подготовить и издать в 1970 г. сборник воспоминаний ветеранов соединения. Был учрежден совет по созданию этой истории, в которую вошли 18 человек, в том числе 15 ветеранов [Расширенное заседание... 1970: 320]. Так на базе КНИИЯЛИ стала складываться группа исследователей по истории 110-й кавдивизии под руководством М. Л. Кичикова, в которую входили профессиональные историки, воины национального соединения и их потомки.

Директор КНИИЯЛИ И. К. Илишкин (брат политработника 110-й кавдивизии) и М. Л. Кичиков, раздосадованные оплошностью, вызванной ложью Н. Л. Иванова, решили дезавуировать ее и обратились к А. И. Заднепруку и Д. С. Лебедкину (которые жестче всех подвергли критике Н. Л. Иванова) с предложением написать брошюру, посвященную истории формирования 110-й кавдивизии и ее первым боям. Ветераны согласились и в большой спешке, чтобы успеть попасть в план изданий 1968 г., сделали эту работу.

Однако в том году Калмыцкий обком ВЛКСМ выпустил звуковой альбом «Путь славы 110 ОККД», включавший в себя вводный текст о кавдивизии, выдержки из документов, фотоиллюстрации и звуковые страницы, изготовленные студией грамзаписи «Мелодия», на которых были записаны: репортаж с места героической гибели С. Ф. Заярного, воспоминания ветеранов и местных жителей — очевидцев тех траги- 
ческих дней [Путь славы 1968]. Калмыцкий обком КПСС счел излишним издание двух книг на одну тему в один год. Брошюру А. И. Заднепрука и Д. С. Лебедкина, к изрядной досаде авторов, изъяли из плана изданий и включили в сборник воспоминаний ветеранов 110-й кавдивизии.

Воспоминаний ветеранов оказалось так много, что сборник разделили на две части: первая была посвящена формированию и боям 110-й кавдивизии на Дону [В боях за Дон 1969], вторая - в Битве за Кавказ [В боях за Северный Кавказ 1973].

В первой книге воспоминаний стержневым материалом стала брошюра А. И. Заднепрука и Д. С. Лебедкина. За прошедший год авторы доработали свои мемуары, внесли важные, на их взгляд, дополнения, исправили ряд ошибок, некоторые из которых были весьма существенными. При этом редакторы разделили этот текст по периодам и включили по частям в разные разделы книги, частично в следующую книгу.

Обстоятельное (и во многом уникальное) описание боевых действий 292-го кавполка дали его бывшие командир и комиссар. Первоначально предполагалось, что воспоминания С. И. Ориночко и П. А. Круглякова будут объединены, так как это позволяло выиграть некий объем за счет исключения повторов. Однако после сдачи последних вариантов мемуаров И. К. Илишкин предложил не объединять их, так как это позволяло оценить события тех лет с разных точек зрения. Воспоминания других ветеранов оказались не столь информативны, но они содержали немало ценных сведений о тех или иных эпизодах формирования и начале боевого пути калмыцкого соединения.

М. Л. Кичиков грамотно подошел к задаче составления сборника и постарался включить туда мемуары ветеранов, представляющих все три полка и конно-артиллерийский дивизион, небоевые сферы жизни дивизии (политическая пропаганда и работа тыла). Если какой-то полк оставался неохваченным, то он специально находил ветерана из этой части и уговаривал написать воспоминания (как, например, М. Г. Джунгурова). В результате получилась книга, дающая неплохое представление о процессе формирования и первых боях соединения. Вот как ее оценил сам Мерген Лиджинович: «Bоспоминания, представленные в сборнике, хотя и не одинаковы по объему, по значимости, по форме и стилю, однако в совокупности воссоздают картину боевых действий, развернувшихся в исключительно тяжельх условиях борьбы с во много раз превосходившим в силах противником» [НА КалмНЦ РАН. Ф. 4. ОП. 4. Д. 246. Л. 12].

Работа над этой книгой шла с определенными трудностями. Наряду с объективными проблемами (часть авторов жила в других городах, и М. Л. Кичикову во избежание противоречий приходилось постоянно пересылать рукописи для перекрестной проверки и согласования исправлений) были трудности и субъективного характера. Рукопись «резали» цензоры, а объем книги лимитировало Калмыцкое книжное издательство, выделившее из своего плана всего 5 печатных листов. К счастью, руководство КНИИЯЛИ, используя связи со ставропольскими коллегами, сумело издать рукопись в полном объеме в Ставропольской типографии [В боях за Дон 1969].

Перед началом работы над второй книгой воспоминаний в мае 1969 г. ученые и ветераны национального соединения проехали по местам боев в сентябре 1942 г. январе 1943 г. Из числа ветеранов в поездке участвовали: бывшие офицеры управления дивизии (М. Т. Бимбаев, И. А. Теврюков, начальник оперативного отделения штаба С. Л. Беседин, политработники Б. О. Манцынов и Л. О. Инджиев), ветераны 273-го кавполка (комиссар полка В. А. Даниленко), разведывательного дивизиона (командир Б. Ц. Арбаков и начальник штаба Е. Б. Малыш-Федорцов), тыла дивизии (С. Ц. Куринов, Ц. Е. Буринов, М. С. Быков).

В июле трое ветеранов (Б. О. Манцынов, бывший сотрудник дивизионной газеты С. М. Чурюмов и офицер штаба 292-го кавполка Д. М. Утнасунов) приняли участие в комсомольско-молодежном мотопоходе, прошедшем по тем же местам, что и в майскую поездку. В ходе этих мероприятий, носивших воспитательно-патриотический характер, также осуществлялась и научная работа. Ветераны записали воспоминания местных жителей, почтили память соратников. Работа на местности позволила ветеранам вспомнить многие подзабытые события и факты, уточнить какие-то детали.

Вторая книга вышла лишь в 1973 г. [В боях за Северный Кавказ 1973], хотя ру- 
копись в целом была готова двумя годами ранее. Как и в первой книге, М. Л. Кичиков постарался охватить в мемуарах все три полка, штабную и политическую работу, но конно-артиллерийский и разведывательный дивизионы представлены не были. Кроме того, из первой книги туда «перебросили» фрагменты воспоминаний Д. С. Лебедкина и С. И. Ориночко, посвященные описываемому периоду. Здесь стержневыми материалами выступили мемуары бывших заместитель командира дивизии М. Т. Бимбаева и начальника штаба И. А. Теврюкова. Они, используя архивные документы, в целом неплохо осветили боевой путь 110-й кавдивизии в ходе Битвы за Кавказ, хотя и не обошлось без лакун и сдвижек по датам. Как и в первой книге, весьма обстоятельным (хоть и порезанным цензорами) оказалось описание С. И. Ориночко о своем полку, сражавшемся отдельно от дивизии.

Материал на уровне полков оказался значительно слабее. Бывший комсорг 311-го кавполка М. И. Гучинов предоставил свои дневниковые записи за декабрь 1942 г. - январь 1943 г. Бывшие комиссар 273-го кавполка В. А. Даниленко и командир эскадрона 292-го кавполка Б. М. Морчуков написали весьма фрагментарные воспоминания, в которых привели лишь несколько дат и боевых эпизодов. Составить по ним какое-то цельное представление о боевом пути этих полков в Битве за Кавказ весьма сложно. Удивляет, что для написания воспоминаний не были привлечены такие ветераны, как А. Х. Бамбышев (политработник штаба дивизии), Б. Ц. Арбаков (командир разведывательного дивизиона), М. Х. Барванцыков (командир взвода 292-го кавполка), П. Б. Зурумхинов (офицер штаба 311-го кавполка), Ш. М. Налаев (рядовой) и др., которые, судя по письмам, могли рассказать немало интересного по истории 110-й кавдивизии.

Несмотря на то, что вторая книга описывала почти полгода боев (с августа 1942 г. по январь 1943 г.), по объему она оказалась на треть меньше, чем первая, которая описывала период формирования и 12 дней боев на Дону. По содержанию, которое было весьма неоднородным, вторая книга воспоминаний оказалась заметно слабее первой, особенно на уровне полков. Конечно, вторую книгу так же, как и первую, «резали» цензоры, ли- митировало издательство, но были тому и иные причины: офицеры частей 2-го (273-й и 311-й кавполк) и 3-го (292-й кавполк) формирований, созданных на базе управлений кавалерийских полков Закавказского фронта, не имели крепкой спайки и не являлись патриотами калмыцкого соединения. Офицеры же полков 1-го формирования за полгода укомплектования и обучения сдружились и стали настоящим боевым братством. Неслучайно, что именно офицеры периода формирования независимо от национальности больше всех переживали за честное имя 110-й кавдивизии и, не считаясь ни со временем, ни с состоянием своего здоровья, приложили наибольшие усилия для его реабилитации.

Однако следует заметить, что воспоминания как вид источников очень субъективны и имеют свои недостатки. За прошедшие десятилетия ветераны могли что-то подзабыть, какие-то события в памяти могли наложиться друг на друга, забывались важные детали, смещались даты, путались имена и фамилии. В каких-то случаях ветераны, стремясь «выручить» своего товарища, пытались придумать ему подвиг или не существовавший в реальности эпизод. Например, в завершающей фазе боев на Дону исчезла бо́льшая часть 311-го кавполка (управление полка, 1-й и 2-й эскадроны, артиллерийская батарея) во главе с командиром М. П. Василенко и комиссаром С. Н. Гаряевым, что вызвало определенные вопросы. Тогда некоторые ветераны стали писать в мемуарах, что якобы видели М. П. Василенко и С. Н. Гаряева (вместе или раздельно) после переправы через Маныч. Это никак не спасало положение, поскольку оставалось неясным, куда потом делись штаб полка, эскадроны и батарея. Однако такими «придумками» ветераны изрядно запутали исследователей истории 110-й кавдивизии.

Работу по подготовке воспоминаний очень сильно осложнила цензура, вырезавшая из мемуаров значительные фрагменты, «порочащие» советский строй. Например, из воспоминаний С. И. Ориночко удалили драматический эпизод, когда при отходе 292-го кавполка в район Майкопа он, пытаясь найти свое соединение, вместе с комиссаром прибыл в штаб Северо-Кавказского фронта. Там их обвинили в трусости и бегстве с поля боя и передали особи- 
стам. Приказ о маршруте отступления был дан С. И. Ориночко устно, и «дело запахло трибуналом». С. И. Ориночко и П. А. Круглякова выручил особист 110-й кавдивизии Н. Е. Орден, подтвердивший коллегам получение устного приказа от командира соединения [НА КалмНЦ РАН. Ф. 4. Оп. 4. Д. 96] ${ }^{1}$. Был вырезан и эпизод из воспоминаний Д. С. Лебедкина о том, что во время движения к фронту в дивизии осудили 3-4 трусов, отрезавших себе два пальца на правой руке [НА КалмНЦ РАН. Ф. 4. Оп. 4. Д. 62]. Исключили полностью воспоминания М. Х. Самбаева, в которых говорилось о том, что во время отступления через Краснодарский край десятки кубанских казаков бежали из частей в родные станицы с лошадьми и оружием [НА КалмНЦ РАН. Ф. 4. Оп. 4. Д. 45. Л. 24]. К счастью, бо́льшая часть первых вариантов мемуаров с правкой редакторов сохранилась в архиве КалмНЦ РАН и может быть восстановлена.

Помимо работы по сбору воспоминаний, активно шла поисковая работа в архивах, прежде всего в ЦАМО. Поскольку бо́льшая часть документов калмыцкого соединения исчезла, пришлось вести поиск сведений в фондах вышестоящих объединений и соседних соединений. Первоначально поиск осуществлялся М. Л. Кичиковым, затем подключились другие члены его группы. Найденные документы позволили ввести в оборот неизвестные ранее сведения или уточнить воспоминания ветеранов. Например, А. И. Заднепрук и С. И. Ориночко в письмах М. Л. Кичикову утверждали, что 110-я кавдивизия никогда не входила в 51-ю армию, а в 37-ю армию попала из состава 9-го кавкорпуса Южного фронта [НА КалмНЦ РАН. Ф. 4. Оп. 4. Д. 88. Л. 3-4]. Только в марте 1968 г. М. Л. Кичикову в ЦАМО удалось найти документы о том, что 12 июня 110-я кавдивизия была передана в состав 51-й армии из кавкорпуса Б. А. Погребова, который вплоть до своего разгрома не был утвержден Ставкой ВГК и номера не имел. Что касается 9-го кавкорпуса, то он был расформирован еще в апреле 1942 г. на Западном фронте.

Другой аналогичный спор привел, к сожалению, к неправильным выводам.

${ }^{1}$ В этом деле раздельная пагинация, поэтому номера листов не указываются.
А. И. Заднепрук и Д. С. Лебедкин настаивали на том, что в боях на Дону 311-й кавполк занимал позиции на правом фланге соединения [НА КалмНЦ РАН. Ф. 4. Оп. 4. Д. 62]. Ветеранов 311-го кавполка уцелело немного, причем офицеры взводного уровня давали противоречивую информацию о местоположении части. М. Л. Кичиков нашел приказ о занятии 311-м кавполком позиций во 2-м эшелоне, и ветераны вынужденно согласились с ним.

Полученные результаты исследований нашли отражение как в научных статьях и главах коллективных монографий, автором которых был М. Л. Кичиков [Кичиков 1967; Кичиков 1968а; Кичиков 1968б; Кичиков 1970а; Кичиков 1970б; Кичиков 1974; и др.], так и в публикациях в газетах и журналах [Бадьминов 1972; 1975; Бимбаев 1973; Зодбаев 1975; Илишкин 1970; Илишкин 1977; Ипполитова 1974; Кичиков 1971; Кичиков 1975; Оглаев 1970; Тачиев 1968; и др.].

В те же годы выходили работы и за пределами Калмыкии, в которых упоминалась 110-я кавдивизия: воспоминания А. А. Гречко [Гречко 1967: 54, 105, 174, 188, 423; и др.], С. М. Штеменко [Штеменко 1968], обобщающая книга по истории Закавказского округа [Краснознаменный Закавказский 1969: 204] и др. Однако там были лишь фрагментарные упоминания о калмыцкой дивизии.

Основной центр исследований по ее истории оставался в Калмыкии. Исследователи группы М. Л. Кичикова все эти годы продолжали работать над своей главной задачей: написанием полноценной книги по истории национального соединения. Самой серьезной проблемой для них оставалась нехватка архивных документов. Исследователи (М. Л. Кичиков, А. И. Заднепрук, М. И. Гучинов и др.) неоднократно выезжали в Архив Министерства обороны (с 1992 г. - ЦАМО), чтобы разыскать недостающие $90 \%$ дел из сданного по описи архива 110-й кавдивизии, но успеха не достигли.

Некоторые ветераны умерли или не смогли заниматься активной работой по состоянию здоровья и иным причинам. В группу включились новые коллеги. Для написания рукописи было выбрано пять человек: три ветерана (М. Т. Бимбаев, А. И. Заднепрук, М. И. Гучинов) и два по- 
томка воинов 110-й кавдивизии (А. С. Заярный и Н. У. Илишкин).

Один из наиболее активных ветеранов А. И. Заднепрук и сын комиссара А. С. Заярный написали главы, посвященные истории формировании соединения и его боев на Дону. М. И. Гучинов, являвшийся в тот период руководителем архивной службы Калмыцкой АССР, стал автором главы, посвященной участию 110-й кавдивизии в Битве за Кавказ. Н. У. Илишкин, уже в те годы бывший известным в Калмыкии журналистом и собравший большое количество воспоминаний и материалов о земляках-участниках Великой Отечественной войны, выступил автором глав, посвященных деятельности бывших воинов национального соединения после его расформирования. М. Т. Бимбаев (ветеран Гражданской войны и спецопераций ГРУ в Монголии и Тибете, самый авторитетный на тот период ветеран Великой Отечественной войны в Калмыкии) в те годы активно участвовал во многих патриотическо-воспитательных мероприятиях в республике и за ее пределами. Он стал соавтором 5-й главы, посвященной этой тематике. Сам М. Л. Кичиков почему-то в число авторов не попал. Научным редактором книги был К. П. Катушов, являвшийся уже секретарем Калмыцкого обкома КПСС по идеологии.

В ходе работы эта группа неоднократно собиралась, обсуждала написанные главы и параграфы, решала различные вопросы, которые возникали в ходе работы. В ряде случаев авторы сталкивались с нестыковками и были вынуждены решать эти противоречия: либо в пользу одного из свидетельств, либо вовсе опуская нерешенную проблему. Например, такой проблемой оказался вопрос: куда в боях на Дону делась бо́льшая часть 311-го кавполка? Когда немцы создали плацдарм напротив Мелиховской, в стыке позиций 273-го и 292-го кавполков, для его блокирования из резерва выдвинули 3-й и 4-й эскадроны 311-го кавполка под руководством зам. командира полка А. К. Темирова. Однако управление полка, 1-й и 2-й эскадроны и артиллерийская батарея из описания боев исчезли. Пытаясь хоть как-то «пристроить» подразделения 311-го кавполка, соавторы ошибочно предположили, что батарея действо- вала вместе с конно-артиллерийским дивизионом, а 2-й эскадрон - вместе с 273-м кавполком. Вопрос об управлении полка во главе с командиром и комиссаром и 1-м эскадроне так и остался открытым. Вообще описание боев 311-го кавполка на Дону дано фрагментарно.

Очень важную роль в этой группе сыграл полковник А. С. Заярный. Он вел активную переписку с ветеранами национального соединения, осуществил редакторскую правку не только своих глав, но и всей рукописи с точки зрения соответствия военным реалиям как человек с классическим военным образованием. Кроме того, в его подчинении были подразделения, которые в тот момент оснащали ЦАМО оборудованием для микрофильмирования. Пользуясь имеющимися связями, А. С. Заярный подбирал для А. И. Заднепрука и М. И. Гучинова фонды, описи и дела, которые следовало обработать. Именно Альберт Сергеевич стал автором карт по истории 110-й кавдивизии. Их важность и уникальность подчеркивает тот факт, что на протяжении последующих трех десятилетий иных карт по истории соединения не было.

Результатом многолетнего кропотливого труда авторского коллектива стала книга, получившая в окончательном варианте название «В годы суровых испытаний» [В годы... 1976]. Эта книга, написанная простым и понятным языком, быстро стала бестселлером, дважды переиздавалась [В годы... 1981; 2003], что для калмыцкой историографии было весьма редким явлением. В ней освещается история формирования и всего боевого пути 110-й Калмыцкой кавдивизии. Конечно, из-за отсутствия большей части архивных документов авторам не удалось решить все проблемы, но они смогли создать достаточно цельную историю национального соединения, опровергнув все мифы о «разбежавшейся дивизии». В историографии истории Калмыкии эта книга на долгие годы стала классикой, от которой отталкивались другие исследователи.

К сожалению, в 1977 г. М. Л. Кичикову по семейным обстоятельствам пришлось переехать в другой регион. После этого деятельность группы исследователей истории 110-й кавдивизии фактически прекратилась. 


\section{Источники}

В боях за Дон 1969 - В боях за Дон: воспоминания воинов 110-й Отдельной Калмыцкой кавалерийской дивизии / сост. и науч. ред. М. Л. Кичиков. Элиста: Калм. кн. изд-во, 1969. $180 \mathrm{c}$.

В боях за Северный Кавказ 1973 - В боях за Северный Кавказ: воспоминания воинов 110-й Отдельной Калмыцкой кавалерийской дивизии / сост. и науч. ред. М. Л. Кичиков. Элиста: Калм. кн. изд-во, 1973. 124 с.

Гречко 1967 - Гречко А. А. Битва за Кавказ. М.: Воениздат, 1967. 424 с.

Калмыкия... 1966 - Калмыкия в Великой Отечественной войне 1941-1945 гг.: документы и материалы / сост.: М. Л. Кичиков, Б. С. Санджиев, Ю. О. Оглаев. Элиста: Калм. кн. издво, 1966. 552 с.

Краснознаменный Закавказский 1969 - Краснознаменный Закавказский: Очерки истории Краснознаменного Закавказского военного округа. М.: Воениздат, 1969. 445 с.

Материалы... 1970 - Материалы совещания по вопросу создания истории 110 Отдельной калмыцкой кавалерийской дивизии // Ученые записки [КНИИЯЛИ]. Серия историческая. Вып. 9. Элиста: КНИИЯЛИ, 1970. C. 300-313.

НА КалмНЦ РАН - Научный архив Калмыцкого научного центра РАН.

НА РК - Национальный архив Республики

\section{Sources}

Kalmyk Scientific Center of the RAS, Scientific Archive.

Ministry of Defense of the Russian Federation, Central Archive.

National Archive of the Republic of Kalmykia.

$110^{\text {th }}$ Separate Kalmyk Cavalry Division: Materials of the establishing meeting. In: Scholarly Notes. Series 'History'. Vol. 9. Elista: Kalmyk Research Institute of Language, Literature and History, 1970. Pp. 300-313. (In Russ.)

$273^{\text {rd }}$ Cavalry Regiment: Defense of RazdorskayaMelekhovskaya section of the Don River. In: The Great Patriotic War of 1941-1945. Collected Tactical Training Situations for Cavalry Units. Moscow: Voenizdat, 1949. Pp. 82-87. (In Russ.)

Chernev N. I. The Way of Glory. Album. Elista: Kalmykia Book Publ., 1968. 22 p., 2 phonograph records. (In Russ.)

Grechko A. A. The Battle for the Caucasus. Moscow: Voenizdat, 1967. 424 p. (In Russ.)

Kalmyk Research Institute of Language, Literature
Калмыкия.

НКВД-МВД... 2008 - НКВД-МВД СССР в борьбе с бандитизмом и вооруженным националистическим подпольем на Западной Украине, в Западной Белоруссии и Прибалтике / сост. Н. И. Владимирцев, А. И. Кокурин. М.: Объединенная редакция МВД, 2008. 369 c.

Оборона... 1949 - Оборона 273-м кп р. Дон в районе Раздорская, Мелеховская // Сборник тактических примеров боевых действий кавалерийского полка по опыту Великой Отечественной войны (1941-1945 гг.). М.: Воениздат, 1949. С. 82-87.

Путь славы 1968 - Путь славы: альбом / сост. Н. И. Чернев. Элиста: Калм. кн. изд-во, 1968. 22 с., 2 грампластинки.

Расширенное заседание... 1970 - Расширенное заседание ученого совета Калмыцкого НИИяЛИ // Ученые записки [КНИИЯЛИ]. Серия историческая. Вып. 9. Элиста: КНИИЯЛИ, 1970. С. 314-321.

ЦАМО - Центральный архив Министерства обороны РФ.

Шарапов 1966 - Шарапов M. C. От Москвы до Берлина. Элиста: Калм. кн. изд-во, 1966. $72 \mathrm{c}$.

Штеменко 1968 - Штеменко С. М. Генеральный штаб в годы войны. М.: Воениздат, $1968.416 \mathrm{c}$.

and History: Enlarged meeting of the Academic Board. In: Scholarly Notes. Series 'History'. Vol. 9. Elista: Kalmyk Research Institute of Language, Literature and History, 1970. Pp. 314-321. (In Russ.)

Kichikov M. L. (comp., ed.) In Battles for the Don: Memoirs by Soldiers of the $110^{\text {th }}$ Separate Kalmyk Cavalry Division. Elista: Kalmykia Book Publ., 1969. 180 p. (In Russ.)

Kichikov M. L. (comp., ed.) In Battles for the North Caucasus: Memoirs by Soldiers of the $110^{\text {th }}$ Separate Kalmyk Cavalry Division. Elista: Kalmykia Book Publ., 1973. 124 p. (In Russ.)

Kichikov M. L. et al. (comps.) Kalmykia in the Great Patriotic War of 1941-1945: Documents and Materials. Elista: Kalmykia Book Publ., 1966. 552 p. (In Russ.)

Sharapov M. S. From Moscow to Berlin. Elista: Kalmykia Book Publ., 1966. 72 p. (In Russ.)

Shtemenko S. M. General Staff of the Soviet Armed Forces during the Great Patriotic War. Moscow: Voenizdat, 1968. 416 p. (In Russ.)

Stuchenko A. (ed.) The Red Banner Transcaucasian: Essays on the History of the Transcaucasian 
Military District. Moscow: Voenizdat, 1969 445 p. (In Russ.)

Vladimirtsev N. I., Kokurin N. I. (comps.) NKVDMVD of the USSR: Struggling against Banditry

\section{Публицистика}

Бадьминов 1972 - Бадьминов Н. «Тюльпан показался сгустком крови»: воспоминания воина 110-й ОККД // Комсомолец Калмыкии. 1972. 9 мая (№ 55). С. 2.

Бадьминов 1975 - Бадьминов Н. Пером и штыком // Советская Калмыкия. 1975. 9 января (№ 6). C. 4.

Бимбаев 1973 - Бимбаев М. 110-я идет в наступление: [к 30-летию боев за Кавказ] // Советская Калмыкия. 1973. 6 января (№ 5). С. 4.

Зодбаев 1975 - Зодбаев М. Политрук 110-й ОККД // Степная новь. 1975. 26 июля (№ 76). С. 4.

Илишкин 1970 - Илишкин Н. Парни из комсомольского эскадрона // Илишкин Н. По зову Родины. Элиста: Калм. кн. изд-во, 1970.

\section{Mass Media Periodicals}

Badminov N. Tulip resembled a clot of blood: memoirs by soldier of $110^{\text {th }}$ Cavalry Division. Komsomolets Kalmykii. 1972 May 9. No. 55. (In Russ.)

Badminov N. With pen and bayonet. Sovetskaya Kalmykiya. 1975, January 9. No. 6. (In Russ.)

Bimbaev M. $110^{\text {th }}$ Cavalry Division under attack. Sovetskaya Kalmykiya. 1973, January 6. No. 5. (In Russ.)

Ilishkin N. Boys from Komsomol squadron. In: Ilishkin N. The Call of Motherland. Elista: Kalmykia Book Publ., 1970. Pp. 42-48. (In Russ.)

Ilishkin N. Brave commander: colonel V. P. Panin,

\section{Литература}

В годы... 1976 - В годы суровых испытаний: боевой путь 110-й Отдельной Калмыцкой кавалерийской дивизии / авт.: А. И. Заднепрук, А. С. Заярный, М. И. Гучинов, Н. У. Илишкин, М. Т. Бимбаев. Элиста: Калм. кн. изд-во, 1976. 239 с.

В годы... 1981 - В годы суровых испытаний: боевой путь 110-й Отдельной Калмыцкой кавалерийской дивизии / авт.: А. И. Заднепрук, А. С. Заярный, М. И. Гучинов, Н. У. Илишкин, М. Т. Бимбаев. 2-е изд., испр. и доп. Элиста: Калм. кн. изд-во, 1981. $235 \mathrm{c}$.

В годы... 2003 - В годы суровых испытаний: боевой путь 110-й Отдельной Калмыцкой кавалерийской дивизии / авт.: А. И. За-
And Armed Nationalist Underground in Western Ukraine, Western Belorussia, and the Baltic. Moscow: Ministry of Internal Affairs of Russia, 2008. 369 p. (In Russ.)

C. $42-48$.

Илишкин 1977 - Илишкин Н. Зөргтә командир: 110-ч Хальмг онц дивизин командир, полковник В. П. Панина тускар // Хальмг үнн. 1977. 1 октября (№ 196). Х. 4.

Ипполитова 1974 - Ипполитова Н. Создается история дивизии: 110-й ОККД // Советская Калмыкия. 1974. 10 июля (№ 133). С. 4.

Кичиков 1971 - Кичиков М. Л. Во имя жизни на земле // Советская Калмыкия. 1971. 8 мая. C. 4.

Кичиков $1975-$ - ичиков М. Л. В боях за Родину // Теегин герл. 1975. № 1. С. 3-36.

Оглаев 1970 - Оглаев Ю. Он был храбрым командиром // Комсомолец Калмыкии. 1970. 25 апреля (№ 50). С. 3.

head of $110^{\text {th }}$ Kalmyk Cavalry Division. Khalmg ünn. 1977, October 1. No. 196. (In Kalm.)

Ippolitova N. $110^{\text {th }}$ Kalmyk Cavalry Division: Creation of chronicles underway. Sovetskaya Kalmykiya. 1974, July 10. No. 133. (In Russ.)

Kichikov M. L. In battles for Motherland. Teegin gerl. 1975. No. 1. Pp. 3-36. (In Russ.)

Kichikov M. L. In the name of life. Sovetskaya Kalmykiya. 1971, May 8. (In Russ.)

Oglaev Yu. He was a brave commander. Komsomolets Kalmykii. 1970, April 25. No. 50. (In Russ.)

Zodbaev M. Politruk of $110^{\text {th }}$ Kalmyk Cavalry Division. Stepnaya nov'. 1975, July 26. No. 76. (In Russ.)

днепрук, А. С. Заярный, М. И. Гучинов, Н. У. Илишкин, М. Т. Бимбаев. 3-е изд., испр. и доп. Элиста: Калм. кн. изд-во, 2003. $335 \mathrm{c}$.

Заярный, Очиров 2017 - Заярный С. А., Очиров У. Б. 110-я отдельная Калмыцкая кавалерийская дивизия на защите донских переправ и ее роль в спасении части войск Южного фронта летом 1942 г. // Вестник Калмыцкого института гуманитарных исследований РАН. 2017. № 6. С. 43-61. DOI: 10.22162/2075-7794-2017-34-6-43-61

Кичиков 1967 - Кичиков М. Л. Трудящиеся Калмыцкой АССР в борьбе за Дон и Северный Кавказ (1941-1942 гг.) // К научной сессии по истории и культуре народов Северного Кавказа и Дона, посвященной 50-летию 
Великой Октябрьской социалистической революции (Тезисы докладов и сообщений). Элиста: [б. и.], 1967. С. 19-24.

Кичиков 1968а - Кичиков М. Л. О некоторых вопросах истории Калмыкии в годы Великой Отечественной войны // Ученые записки [Калмыцкого НИИЯЛИ]. Вып. 6. Серия историческая. Элиста: КНИИЯЛИ, 1968. С. $163-194$.

Кичиков 19686 - Кичиков М. Л. Калмыкия в годы Великой Отечественной войны 19411945 гг. // Калмыкия в истории СССР: пособие для изучающих историю родного края / под общ. ред. М. Л. Кичикова. Элиста: Калм. кн. изд-во, 1968. С. 115-135.

Кичиков 1970а - Кичиков М. Л. Во имя победы над фашизмом. Элиста: Калм. кн. изд-во, 1970. 208 c.

Кичиков $1970 б-$ Кичиков М. Л. Калмыцкая АССР в годы Великой Отечественной войны (1941-1945 гг.) // Очерки истории Калмыцкой АССР. Эпоха социализма. М.: Наука, 1970. С. 276-316.

Кичиков $1974-$ - Кичиков М. Л. К историографии боевого пути 110-й Отдельной Калмыцкой кавалерийской дивизии // Ученые запи-

\section{References}

Kichikov M. L. $110^{\text {th }}$ Kalmyk Cavalry Division and its campaign record: Historiography revisited. In: Scholarly Notes. Series 'History'. Vol. 10. Elista: Kalmyk Research Institute of Language, Literature and History, 1974. Pp. 219-226. (In Russ.)

Kichikov M. L. In the Name of Victory over Fascism. Elista: Kalmykia Book Publ., 1970. 208 p. (In Russ.)

Kichikov M. L. Kalmyk ASSR during the Great Patriotic War of 1941-1945. In: Essays on the History of Soviet Kalmykia. Socialist Era. Moscow: Nauka, 1970. Pp. 276-316. (In Russ.)

Kichikov M. L. Kalmykia during the Great Patriotic War, 1941-1945. In: Kichikov M. L. (ed.) Kalmykia in Soviet History. Elista: Kalmykia Book Publ., 1968. Pp. 115-135. (In Russ.)

Kichikov M. L. Some issues of Kalmykia's history during the Great Patriotic War revisited. In: Scholarly Notes. Series 'History'. Vol. 6. Elista: Kalmyk Research Institute of Language, Literature and History, 1968. Pp. 163-194. (In Russ.)

Kichikov M. L. Workpeople of Kalmyk ASSR in battles for the Don and North Caucasus, 1941-1942. In: History and Culture of North Caucasus and Don Peoples. Jubilee congress abstracts. Elista, 1967. Pp. 19-24. (In Russ.) ски Калмыцкого НИИялИ. Вып. 10. Серия историческая. Элиста: КНИИЯЛИ, 1974. С. 219-226.

Очиров 2018 - Очиров У. Б. Аферист в бою: военная биография Н.Л. Иванова // История: факты и символы. 2018. № 4 (17). С. 120-130.

Очиров 2019 - Очиров У. Б. Воины 110-й Калмыцкой кавалерийской дивизии в Широклаге: статистическое исследование // Magna adsurgit: historia studiorum. 2019. № 1. C. 2335. DOI: $10.22162 / 2541-9749-2019-7-1-23-35$

Очиров, Тепкеев 2017 - Очиров У. Б., Тепкеев B. T. Научное наследие М. Л. Кичикова: к 95-летию со дня рождения // Magna adsurgit: historia studiorum. 2017. № 2. C. 111-120. DOI: $10.22162 / 2541-9749-2017-4-2-111-120$

Тачиев 1968 - Тачин А. Олнд өврмж, баһчудт бахмж // Кишгтә улс: очеркс. Элст, 1968. X. 13-23.

Убушаев 1991 - Убушаев В. Б. Калмыки: выселение и возвращение. Элиста: Санан, 1991. $96 \mathrm{c.}$

Убушаев 2007 - Убушаев В. Б., Убушаев К. В. Калмыки: выселение, возвращение, возрождение. 1943-1957 гг. Элиста: КалмГУ, 2007. 496 c.

Ochirov U. B. Swindler in fight: N. L. Ivanov's military biography. History: Facts and Symbols. 2018. No. 4 (17). Pp. 120-130. (In Russ.)

Ochirov U. B. Soldiers of the $110^{\text {th }}$ Kalmyk Cavalry Division in Shirokovsky forced labor camp: A statistical study. Magna adsurgit: historia studiorum. 2019. No. 1. Pp. 23-35. (In Russ.)

Ochirov U. B., Tepkeev V. T. Mergen L. Kichikov's scientific heritage: Celebrating the $95^{\text {th }}$ birthday. Magna adsurgit: historia studiorum. 2017. No. 2. Pp. 111-120. (In Russ.)

Tachin A. Astonishment to all, admiration to youth. In: The Blessed People. Essays. Elista, 1968. Pp. 13-23. (In Kalm.)

Ubushaev V. B. The Kalmyks: Deportation and Return. Elista: Sanan, 1991. 96 p. (In Russ.)

Ubushaev V. B., Ubushaev K. V. The Kalmyks, 1943-1957: Deportation, Return, and Revival. Elista: Kalmyk State University, 2007. 496 p. (In Russ.)

Zadnepruk A. I. et al. The Harsh Years: Campaign Record of the $110^{\text {th }}$ Separate Kalmyk Cavalry Division. Elista: Kalmykia Book Publ., 1976. 239 p. (In Russ.)

Zadnepruk A. I. et al. The Harsh Years: Campaign Record of the $110^{\text {th }}$ Separate Kalmyk Cavalry Division. $2^{\text {nd }}$ ed., rev. and suppl. Elista: Kalmykia Book Publ., 1981. 235 p. (In Russ.) 
Zadnepruk A. I. et al. The Harsh Years: Campaign Record of the $110^{\text {th }}$ Separate Kalmyk Cavalry Division. 3rd ed., rev. and suppl. Elista: Kalmykia Book Publ., 2003. 335 p. (In Russ.)

Zayarny S. A., Ochirov U. B. The $110^{\text {th }}$ Separate Kalmyk Cavalry Division in the defensive battles for Don River crossings and its role in the rescue of some Sothern Front units in the summer of 1942. Bulletin of the Kalmyk Institute for Humanities of the RAS (Oriental Studies). 2017. No. 6. Pp. 41-59. (In Russ.) DOI: 10.22162/2075-7794-2017-34-6-43-61 